\title{
The influence of selected mining and natural factors on the sinkhole creation hazard based on the case study
}

\author{
Piotr Strzałkowski ${ }^{1}$ (D)
}

Received: 24 April 2019 / Accepted: 14 January 2021 / Published online: 2 February 2021

(c) The Author(s) 2021

\begin{abstract}
The formation of sinkholes, especially in developed areas, constitutes a considerable hazard to the public safety. Due to the above, the subject of the paper is a significant and current issue. The paper includes a case study of sinkholes forming over shallow mine galleries. Calculations of the workings' stability and the impact of the underground mining exploitation have been conducted. The probability of sinkhole formation has been determined as well. The time of sinkholes formation did not correspond with the time in which the mining exploitation affected the gallery workings and the moment in time for which the rock mass deformations caused by the exploitation were at the highest level. The performed exploitation caused occurrence of cracks in the rock mass over the working. This allowed the transportation of the loose overburden by rainwater to workings and as a result sinkholes were created—suffosion occurred. The Quaternary overburden built of sands and sandy loams was probably washed out by rainwater, which led to the formation of sinkholes. In all locations, where shallow voids exist at a depth up to $100 \mathrm{~m}$ and the overburden consists of loose rocks, one should consider the probability of sinkholes formation.
\end{abstract}

Keywords Ground deformations $\cdot$ Predicting sinkholes $\cdot$ Suffosion

\section{Introduction}

Sinkholes forming at the land surface are serious problem posed to the public safety. Their occurrence is related to the collapse of shallow voids that are present inside the rock mass. The caverns may be a result of geological processes, mostly karst phenomena, or occur due to human activity. Depending on the genesis of the caverns, the sinkholes forming above may be classified as natural or of anthropogenic origin (Chudek et al. 1988; Augarde et al. 2003). Numerous publications present cases of sinkhole formation due to the loss of stability of karst voids in many different countries: in Florida, USA (Brinkmann et al. 2008; Xiao et al. 2016), in Maryland, USA (Doctor et al. 2008), in Greece (Barthellos et al. 2012; Papadppoulou et al. 2013), in Russia (Baryakh and Fedoseev 2011) and in China (Jiang et al. 2017). The voids that are formed in the rock mass due to human activity are mine workings—remainings of mining activity

Piotr Strzałkowski

piotr.strzalkowski@polsl.pl

1 Faculty of Mining, Safety Engineering and Industrial Automation, Silesian University of Technology, Akademicka 2, 44-100 Gliwice, Poland conducted in past times at shallow depths. The above may also include voids which formed due to pipeline failures and precipitation (Mellett and MacCarillo 1996; Scarborough 1996). Instances of sinkholes related to old mining workings do not occur only in Poland (Strzałkowski 2019), but also in many other countries including India (Singh and Dhar 1997) and United States (Hunter 2015). The sinkholes forming in mining areas in China constitute an interesting issue, as the changes in hydrological ratios due to exploitation of various minerals (coal, metal ores) lead to the outflow of karst water to the workings. Along with the suffosion phenomenon, this process generates sinkholes at the surface ( $\mathrm{Li}$ and Zhou 1999). The co-occurrence of both natural and anthropogenic factors may thus be noted.

From the public safety point of view, the assessment of the sinkhole hazard level is significant. Based on that assessment, also the appraisal of suitability of such areas for future economic use may be conducted.

First, it is worth to determine what factors have an impact on the loss of stability of shallow voids. As the causes of the formation of sinkholes in mining areas in India, the authors of the paper (Singh and Dhar 1997) have mentioned: shallow exploitation, tectonic disturbances and the thickness of loose rocks in the overburden. In the paper by (Xiao et al. 
2016), a significant impact of atmospheric conditions on the formation of sinkholes has been noted. The impact was manifested mostly by changes in hydrogeological conditions caused by precipitation. Similarly, the dependence between the number of observed sinkholes and the amount of atmospheric precipitation in Upper Silesia has been noted in the paper (Chudek et al. 1988). In Greece, the formation of sinkholes over karst voids was related, i.e., to the seismic activity, although other natural causes were also considered (Papadppoulou et al. 2013). The authors of the paper provide an estimation of sinkhole formation probability based on an analysis of geological conditions in locations where the sinkholes already occurred and-based on that-they predict the occurrence of new sinkholes in areas characterized by similar conditions. In the paper by (Gutiérrez et al. 2008), it has been noted that such extrapolation is not sufficiently verifiable, and thus, proper protection of structures against sinkholes is a better solution. In the paper (Malinowska and Matonóg 2017), the geological conditions that are favourable for the formation of sinkholes and related to human activity have been indicated (the distribution of further exploitations, vibrations due to traffic). In case of separately occurring voids characterized by predictable dimensions and no action of other external factors, calculations may be performed in a relatively simple and reliable method. The problem of predicting the occurrence of sinkholes due to the loss of the load-bearing capacity of old wooden supports, and thus, the loss of the void's stability, has been considered by Strzałkowski (2019). The assumption of this solution was the lack of any external factors affecting the void. The prediction of the collapse of a karst cavern with the use of numerical methods has been presented in the paper by (Baryakh and Fedoseev 2011). In complicated conditions of co-occurrence of numerous external factors, the problem is more complex. In the paper (Pilecki 2008), while discussing the application of geophysical methods for studying the locations of shallow voids, it has been established that it is difficult to determine the time and location of the sinkhole formation. It should be kept in mind that sinkholes are one of the forms of underground mining impact on the environment (Kratzsch 1983; Whittaker and Redish 1989; Bell et al. 2000). The purpose of this paper is to exhibit the causes behind seven sinkholes created over mining galleries in cases where several factors co-occurred.

\section{Case study}

In the spring of 2008, a series of sinkholes was observed in a forest area. Created sinkholes were arranged along straight line direction-Figs. 1 and 2. The exact moment of their creation is not known-probably they could had been formed during winter, when the area was not monitored by

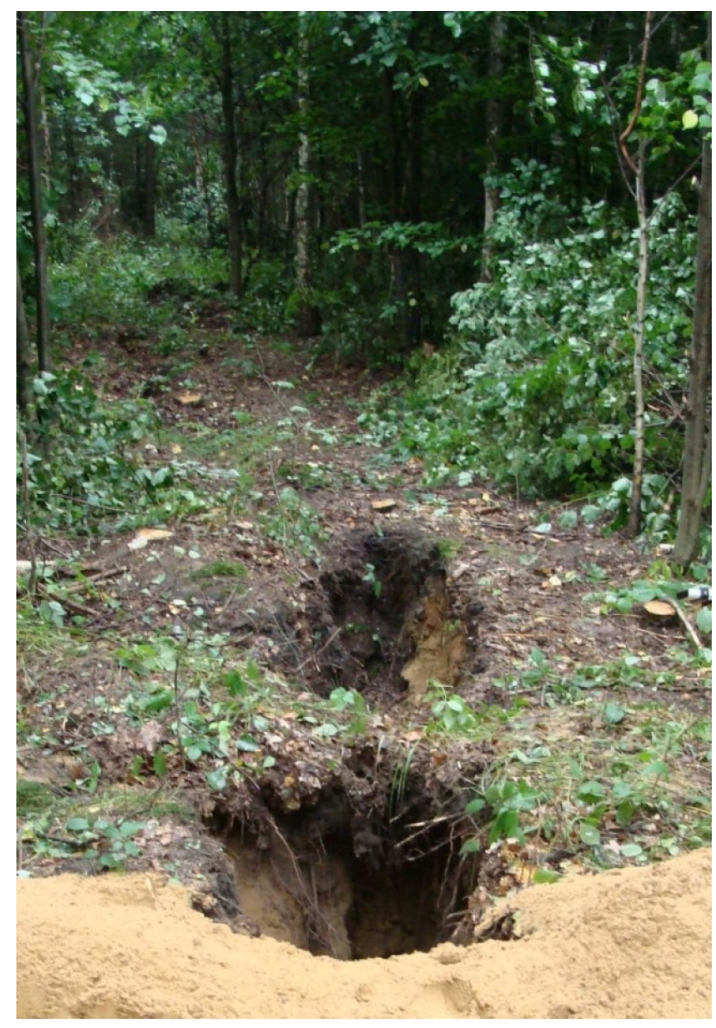

Fig. 1 General view of the series of sinkholes (author M. Gasz)

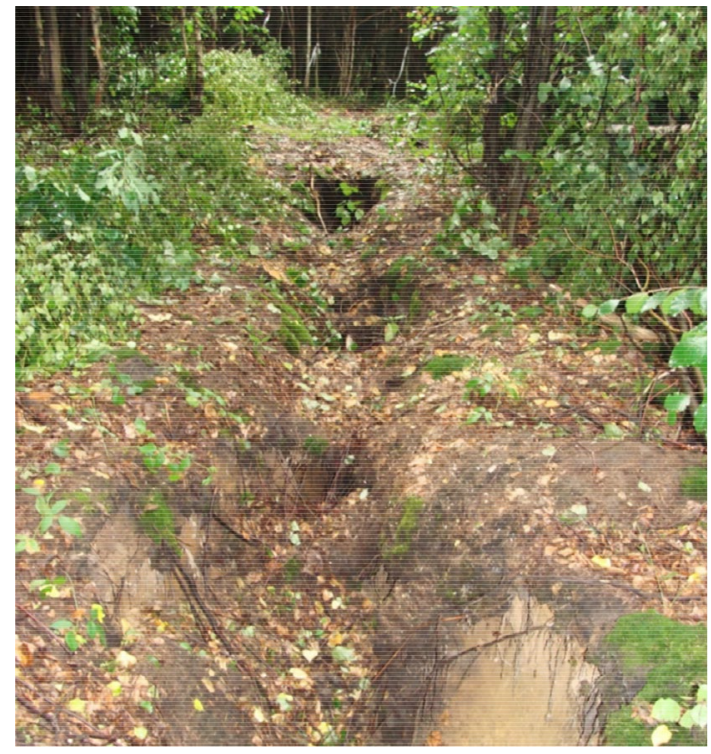

Fig. 2 General view of the series of sinkholes (author M. Gasz)

forest services. The dimensions of the sinkholes were not large-the diameters amounted to approx. 0.5-2 $\mathrm{m}$. The depth of the sinkholes reached as much as approx. $3.5 \mathrm{~m}$ (Fig. 3). Due to the characteristics of the area, the sinkholes posed a hazard both for people and for animals. Due to the 


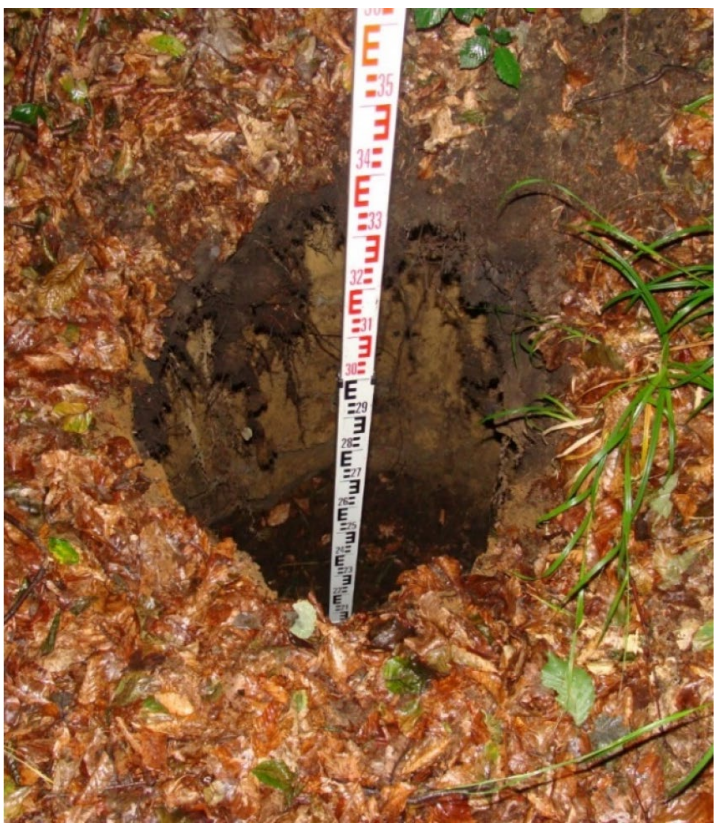

Fig. 3 Sinkhole depth measurement (author M. Gasz)

above, the mine was forced to liquidate the sinkholes by their backfilling with sand.

\section{Lithology and stratigraphy}

In the study area, the rock mass is built of Quaternary overburden strata and productive Carboniferous formations. The overburden consists of sand and sandy loam layers with average thickness of $10 \mathrm{~m}$. Below, Carboniferous strata are found in the form of alternate layers of sandstones, claystone and coal seams. The profile of the rock mass has been presented in Fig. 4.

\section{Characteristics of the mining works}

In the considered area, the deepest extracted coal seam is the 303 seam (coal seam number taken according to Polish classification of Carboniferous layers). The seam was exploited here in the years 1964-68 using longwall system with caving with a height of up to $1.8 \mathrm{~m}$. The depth of the seam in the area of the sinkholes was approx. $67 \mathrm{~m}$. The comparison of the sinkholes locations against the mining map of the seam indicates that the sinkholes were formed over galleries in this seam-Fig. 5.

Subsequently, the mine continued to extract deeper seams. In the years from 1977 to 1980 , exploitation with caving of the seam 314 , located at the depth of $220-255 \mathrm{~m}$, was conducted, with a height of $2.2 \mathrm{~m}$. Starting from 2002, seams $324 / 3$ and 325 were exploited. The

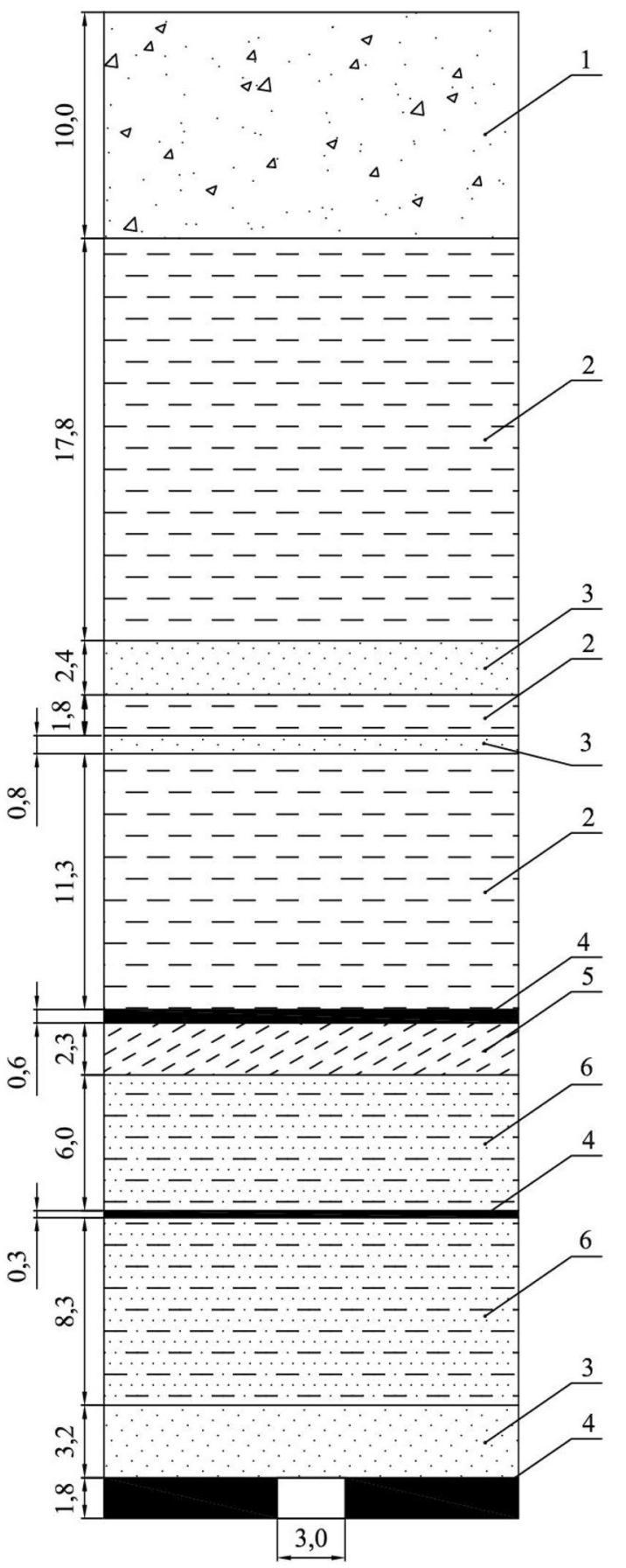

Fig. 4 Lithological profile of the rock mass in the study area. Dimensions in meters. 1 Sand and sandy loam, 2 claystone, 3 sandstone, 4 coal, 5 mudstone, 6 sandy claystone

information regarding the geological and mining conditions of these exploitations are shown in Table 1. The orientation of extracted longwalls in relation to the observed sinkhole locations is shown in Fig. 6. 


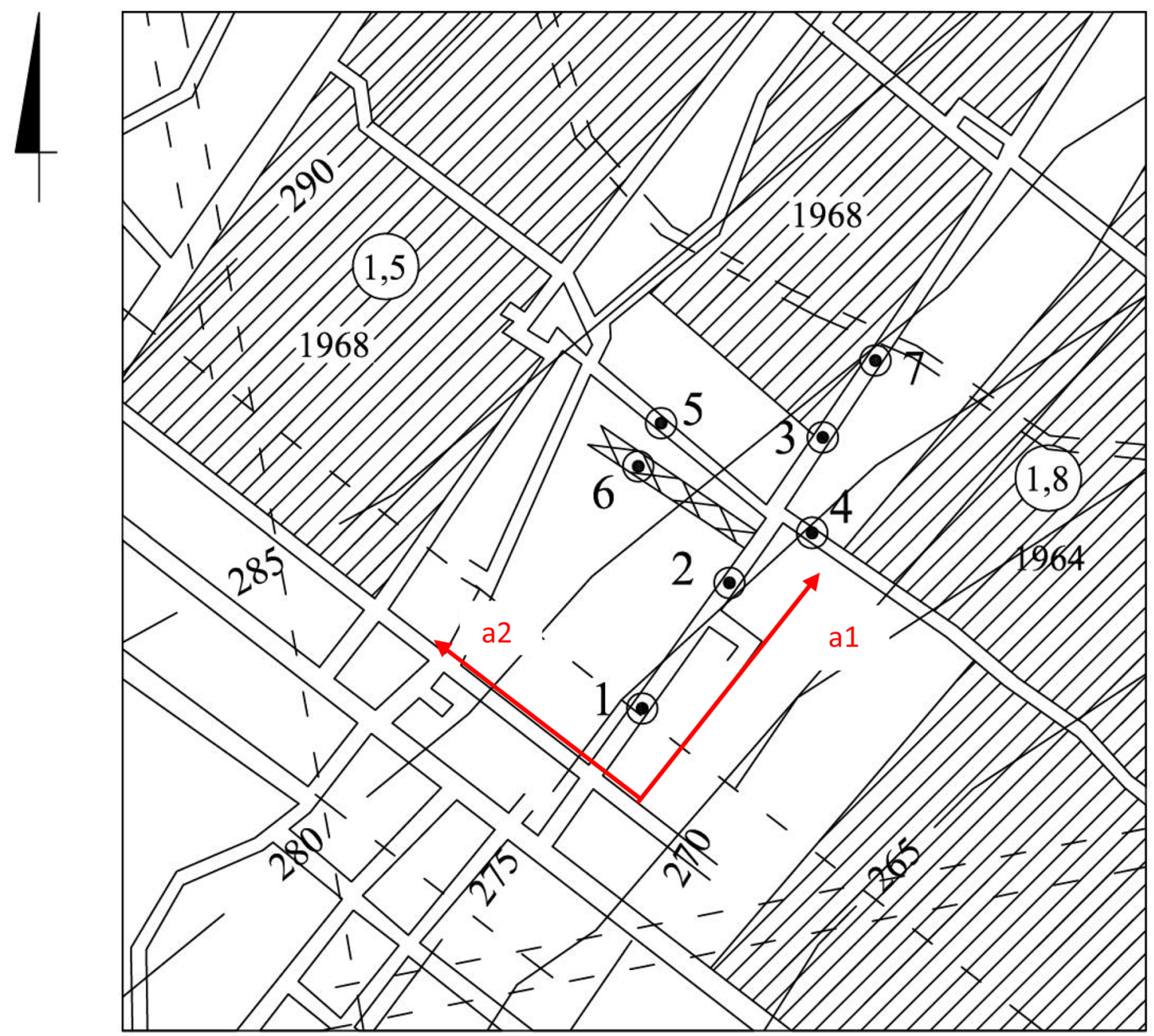

Fig. 5 The map of coal seam 303 and location of the sinkholes 1-7. Scale 1:5000

Table 1 The basic data related to mining and geological conditions of extraction

\begin{tabular}{|c|c|c|c|c|c|c|}
\hline Coal seam & Longwall no & $\begin{array}{l}\text { Beginning of extrac- } \\
\text { tion dd-mm-yyyy }\end{array}$ & $\begin{array}{l}\text { End of extraction } \\
\text { dd-mm-yyyy }\end{array}$ & $\begin{array}{l}\text { Thickness of } \\
\text { coal seam }[\mathrm{m}]\end{array}$ & $\begin{array}{l}\text { Depth of } \\
\text { extraction }[\mathrm{m}]\end{array}$ & $\begin{array}{l}\text { Direction of extraction location } \\
\text { in relation to sinkhole position }\end{array}$ \\
\hline 314 & 1 & 01-01-1980 & $30-09-1980$ & 2.25 & 220 & $\mathrm{~N}$ \\
\hline 314 & 2 & 01-04-1979 & 31-12-1979 & 2.15 & 220 & NW \\
\hline 314 & 3 & 01-05-1978 & 30-04-1979 & 2.25 & 230 & W \\
\hline 314 & 4 & 01-07-1977 & 30-04-1978 & 2.25 & 240 & Downwards \\
\hline 314 & 5 & 01-01-1977 & 30-03-1978 & 2.25 & 255 & $\mathrm{~S}$ \\
\hline $324 / 3$ & 6 & 01-02-2004 & 30-09-2004 & 2.00 & 555 & $\mathrm{NE}$ \\
\hline $324 / 3$ & 7 & 01-07-2003 & $30-09-2003$ & 2.00 & 555 & $\mathrm{~N}$ \\
\hline $324 / 3$ & 8 & 01-06-2002 & $31-12-2002$ & 2.00 & 545 & NW \\
\hline 325 & 9 & 01-02-2006 & $30-09-2006$ & 1.80 & 610 & $\mathrm{~N}$ \\
\hline 325 & 10 & 01-01-2005 & $30-07-2005$ & 1.80 & 600 & $\mathrm{~N}$ \\
\hline 325 & 11 & 01-07-2005 & $30-05-2006$ & 1.70 & 590 & NW \\
\hline
\end{tabular}


Fig. 6 Diagram presenting the location of the extracted longwalls in relation to the calculation point

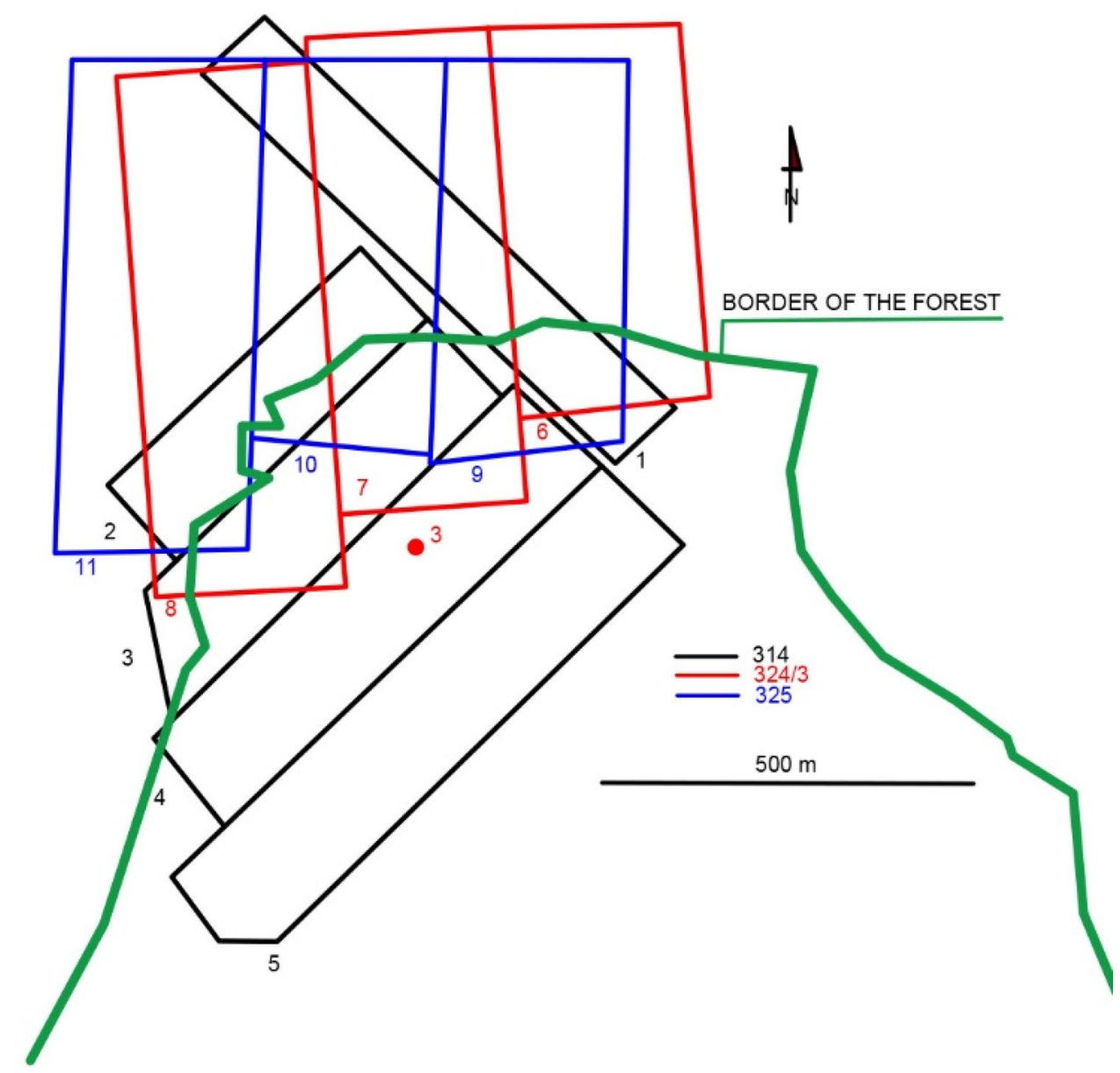

\section{Verification of the condition of stability of the working driven in the 303 seam}

The stability state of the shallow working prior to start of extraction located at greater depth was determined on the basis of pressure arch theory according to A. Sałustowicz, derived from Huber's solution. According to this model, the extreme values of stresses may be calculated by the following formulae (Sałustowicz 1956):

In the floor and roof of working:

$\sigma_{z}=0$

$\sigma_{x}=\sigma_{x \max }=p_{x}\left(1+2 \frac{a}{b}\right)-p_{z}$

where, $\sigma_{\mathrm{x} \text { max }}$-maximal horizontal stress, $\sigma_{\mathrm{z}}$-vertical stress, $a, b$-lengths of the vertical and horizontal axes of the elliptic fracture zone, $n=a / b$ - the length ratio of major axes of ellipse, $p_{z}, p_{x}$-vertical and horizontal components of the primary pressure.

A fracture zone occurs above the working's roof if the following condition is fulfilled: $\sigma_{x \max } \geq R_{r}$

where, $R_{r}$ rock's tensile strength.

If $n<0$, the fracture zone around the working does not occur, as $\sigma_{\mathrm{x} \max }<R_{r}$.

Based on the paper (Kidybiński 1982), the following properties of the rocks have been assumed, while using reduced tensile strength values due to the shallow depth of the considered working. The physical parameters of the strata are presented in Table 2.

Performed calculations indicate that the values of the vertical $\left(p_{z}\right)$ and horizontal $\left(p_{x}\right)$ components of the primary pressure at the depth of $67 \mathrm{~m}$ were $p_{z}=-1.631 \mathrm{MPa}$, $p_{x}=-0.326 \mathrm{MPa}$. For such results, the ratio of the ellipse axes is equal to $n=-1.07$, which means that no stressrelieved zone exists around the working. Thus, in the light of the calculation results, the support was not under load, and the working remained in a self-stability state. 
Table 2 Properties of the rocks from the study area

\begin{tabular}{llllr}
\hline No & Rock & $\gamma[\mathrm{MPa} / \mathrm{m}]$ & $\mathrm{R}_{\mathrm{r}}[\mathrm{MPa}]$ & $\mathrm{h}[\mathrm{m}]$ \\
\hline 1 & Sandy loam & 0.027 & 0.02 & 10.0 \\
2 & Claystone & 0.025 & 0.15 & 17.8 \\
3 & Sandstone & 0.025 & 2.00 & 2.4 \\
4 & Claystone & 0.025 & 0.15 & 1.8 \\
5 & Sandstone & 0.025 & 2.00 & 0.8 \\
6 & Claystone & 0.025 & 0.15 & 11.3 \\
7 & Coal & 0.015 & 0.20 & 0.6 \\
8 & Mudstone & 0.025 & 1.00 & 2.3 \\
9 & Sandy claystone & 0.025 & 0.15 & 6.0 \\
10 & Coal & 0.015 & 0.20 & 0.3 \\
11 & Sandy claystone & 0.025 & 0.15 & 8.3 \\
12 & Sandstone & 0.025 & 2.00 & 3.2 \\
13 & Coal & 0.015 & 0.20 & 1.8 \\
\hline
\end{tabular}

Where: $\gamma$ rock bulk density, $h$ thickness of a given stratum, $R_{r}$ tensile strength

\section{Impact of mining exploitation on the working on the basis of Budryk-Knothe model}

For calculation of continuous deformations state in the vicinity of the considered working, the Budryk-Knothe theory was used (Knothe 1984; Kratzsch 1983). In the considered case, the DEFK-Win software that bases on this model was utilized (Ścigała 2013). Below short basics of Budryk-Knothe model are given.

Final value of subsidence at point $\mathrm{A}(\mathrm{s}, \mathrm{t})$ located on the land surface is determined by the equation:

$w(s, t)=-\frac{a \cdot g}{r^{2}} \iint_{P} f(x-s, y-t) d P$

where, $f(x-s, y-t)$ —so-called, influence function":

$f(x-s, y-t)=\exp \left\{\frac{-\pi\left[(x-s)^{2}+(y-t)^{2}\right]}{r^{2}}\right\}$

$\mathbf{g}$ - thickness of extracted deposit, $\mathrm{m} ; \mathbf{s}, \mathbf{t}$-spatial coordinates of point $\mathbf{A}$ in a Cartesian coordinate system, $\mathrm{m}$; $\mathbf{x}$, $\mathbf{y}$-spatial coordinates of elementary extraction field $\mathbf{d P}, \mathrm{m}$; $\mathbf{P}$ - the area of extracted deposit, $\mathrm{m}^{2}$.

In Eqs. (1) and (2) the following parameters are used: a-coefficient of roof control. Its average value falls into the range of $(0.70,0.85)$ for extraction with caving.

$\mathbf{r}$ - the radius of major influences range, $\mathrm{m}$

In practice, the parameter $\operatorname{tg} \boldsymbol{\beta}$ is often used instead of $\mathbf{r}(\operatorname{tg} \boldsymbol{\beta}=\mathbf{H} / \mathbf{r}$, where $\mathbf{H}$ the depth of extraction). In Upper Silesia Coal Basin average value of $\operatorname{tg} \boldsymbol{\beta}=\mathbf{2}$. Its value is closely tied to rock mass properties.

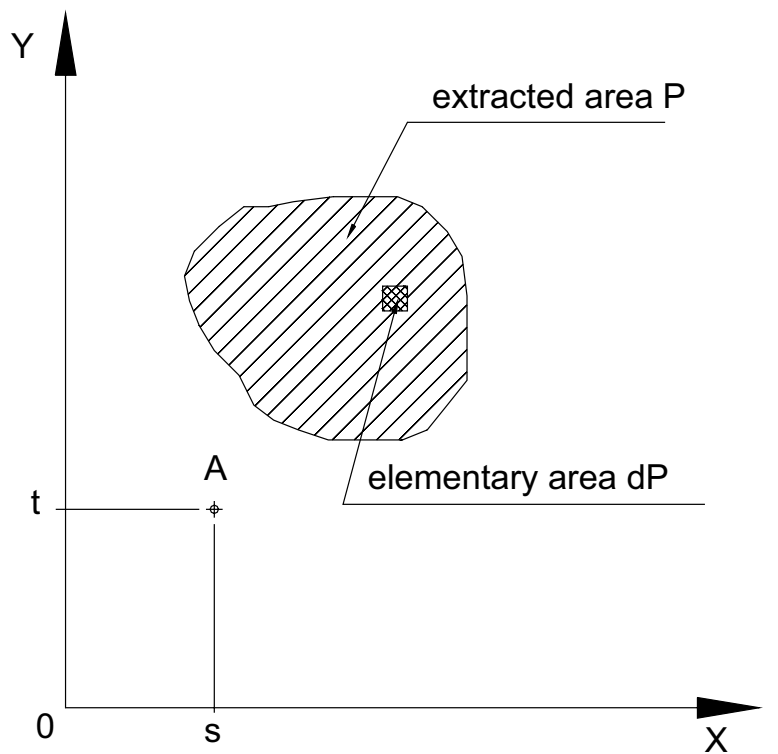

Fig. 7 The explanatory sketch of point A $(s, t)$ location against extracted area for Eqs. (3) and (4)

Location of the point $\mathrm{A}(\mathrm{s}, \mathrm{t})$ against extraction field is shown in Fig. 7.

The deformation indices that describe the subsidence trough are: tilt $\mathbf{T}$, vertical curvature $\mathbf{K}$ and horizontal strain $\varepsilon$. The deformation indices are calculated as corresponding derivatives of subsidence according to the following equations:

$T_{x}=\frac{\partial w}{\partial x}, T_{y}=\frac{\partial w}{\partial y}$

$K_{x}=\frac{\partial^{2} w}{\partial x^{2}}, K_{y}=\frac{\partial^{2} w}{\partial y^{2}}$

$\varepsilon_{x}=B \cdot \frac{\partial^{2} w}{\partial x^{2}}, \varepsilon_{y}=B \cdot \frac{\partial^{2} w}{\partial y^{2}}$

where, $\mathbf{B}$-coefficient of Avierszyn, value of this parameter is usually used as $B=0.32 r$.

The following values were taken for calculations:

- Coefficient of roof control for exploitation with caving$a=0.8$

- Tangent of the major influence range angle $-\operatorname{tg} \beta=2$

- $B=0.32 r$.

So-called "immediate influences" model was used in calculations. A computer simulation of the longwall extraction advance with 10 days step was conducted for the entire range of mining works. 
The exemplary results of calculations are shown for point No. 3, as the calculation results for subsequent points do not differ significantly. Figures 8 and 9 present the distribution of subsidence $(w)$ and maximal horizontal strain (Emax), the horizontal strain along face advance direction (Ea1) and in the perpendicular direction (Ea2) as well as the vertical strain (Ez). The al angle marks the direction of the longwall advance, which extraction probably triggered the sinkholes: $1,2,3,7$. The a2 direction is perpendicular to a1 and thus may be assumed to be related to the direction of the working connected with creation of sinkholes: 4,5 .

\section{Discussion of the obtained calculation results}

The calculation results presented in "Verification of the condition of stability of the working driven in the 303 seam" lead to conclusion that the working-related void in the rock mass should be stable-no stress-relieved zone had formed around the working and thus the support was

Fig. 8 The course of subsidence over time for point No. 3
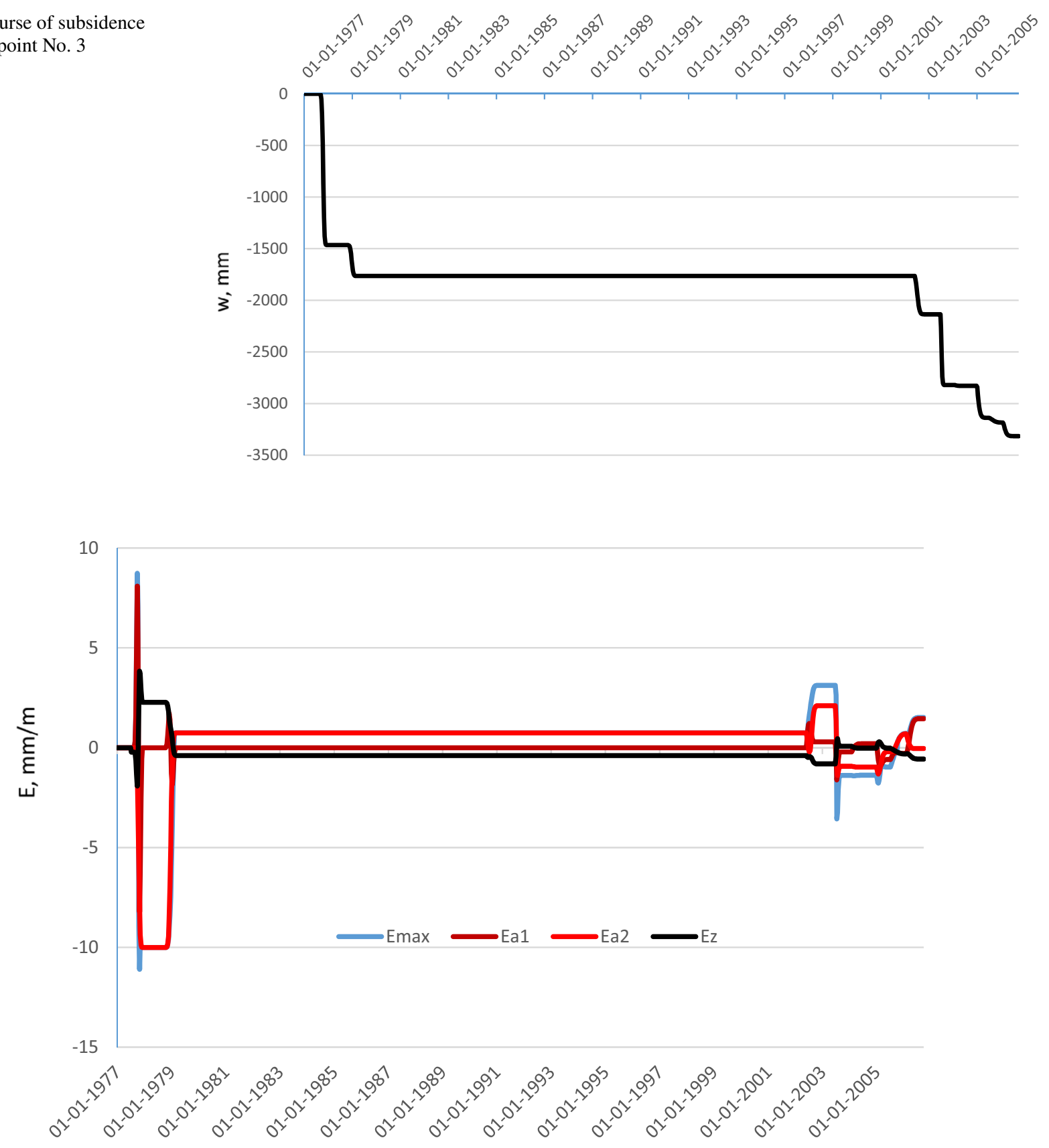

Fig. 9 Horizontal and vertical strain distribution over time for point No. 3 
not under load. Moreover, the support in such case was not necessary. Of course, for safety reasons, the support is usually (though not always) used-calculations are carried out under given assumptions, which do not always have to correspond to real technical needs. The mining exploitation conducted later resulted in the state of deformation presented in the chapter 2.4 of the paper.

As mentioned before, the calculations were performed assuming the "immediate influence" model. The reason for this approach was the lack of data necessary for performing calculations giving the possibility of determining timedependent distribution of deformation state over time. In practice, the deformation process reveals on the surface with a certain delay in relation to the conducted mining works. The working in consideration was affected by the mining exploitation conducted until the end of June 2006 (longwall No 9, coal seam 325). It may be assumed that the effects of the exploitation were finished until the end of June 2007 due to the aforementioned delay in deformation process. Thus, in the light of these calculation results, the sinkholes appeared at a time when the impact of last exploitation had already been finished. On this basis, it can be concluded that the extraction did not cause the excavation to go into a cave-in state. The time when the effects of the exploitation were finished was determined based on the following formula (Strzałkowski and Ścigała 2010):

$T_{k}=0.028 \frac{H}{(\operatorname{tg} \beta)^{0.5}}$

where, $T_{k}$-duration of the deformation process following the end of exploitation or the exploitation becoming distant beyond the impact range ("subsidence cease time"), months; $H$-depth of the exploitation, $m$; $\operatorname{Tg} \beta$ — tangent of the angle of major influence range.
This empirical formula is valid for exploitation carried out with caving in the depth range from 290 to $810 \mathrm{~m}$, with a rock mass characterized by $\operatorname{tg} \beta$ value from 1.60 to 3.30 . The speed of the extraction front differs from $3 \mathrm{~m} /$ day to $5 \mathrm{~m} /$ day.

The final subsidence amounted to approx. $3.3 \mathrm{~m}$ (Fig. 8). Since March 1979 until mid-2002, no exploitation affecting the study area was conducted. The vertical strain (Fig. 9) was in the range from approx. $-1.92 \mathrm{~mm} / \mathrm{m}$ (compression) to approx. $+3.83 \mathrm{~mm} / \mathrm{m}$ (tension, for the exploitation range conducted until the end of October 1977). The final value of the vertical strain amounted to $-0.57 \mathrm{~mm} / \mathrm{m}$. The horizontal strain in the direction of the longwall advance reached however higher values: $-8.22 \mathrm{~mm} / \mathrm{m}$ (compression, for exploitation conducted until the end of October 1977) and $+8.09 \mathrm{~mm} / \mathrm{m}$ (tension, until the end of September 1977). The final value amounted to $1.45 \mathrm{~mm} / \mathrm{m}$. The horizontal strain perpendicular to the longwall advance reached $-10.01 \mathrm{~mm} / \mathrm{m}$ at most (compression for exploitation conducted until the beginning of December 1977) and $+2.10 \mathrm{~mm} / \mathrm{m}$ (tension, for exploitation conducted until mid-October 2002). The final value amounted to $-0.04 \mathrm{~mm} / \mathrm{m}$. Maximal horizontal strain reached $+8.73 \mathrm{~mm} / \mathrm{m}$ for exploitation conducted until the end of September 1977 and then $-11.10 \mathrm{~mm} / \mathrm{m}$ for exploitation conducted to the end of October 1977. Its final value amounted to $+1.51 \mathrm{~mm} / \mathrm{m}$. As it is commonly known, rocks exhibit a tensile strength much lower than their compressive one. Figure 10 presents the results of research by K. Tomiczek (Tomiczek 2007; Strzałkowski and Tomiczek 2015), presenting the dependence between the carboniferous sandstones' tensile strength and yield strain. The roof of the considered working contains sandstone, for which the uniaxial tensile strength was assumed to be $2 \mathrm{MPa}$. As shown in Fig. 10, the yield strain for that rock is $+0.15 \mathrm{~mm} / \mathrm{m}$. Thus, the rock mass deformations must have resulted in the occurrence of fracture zones. Some results (Tomiczek
Fig. 10 Dependence between the uniaxial tensile strength and the yield strain (Tomiczek 2007)

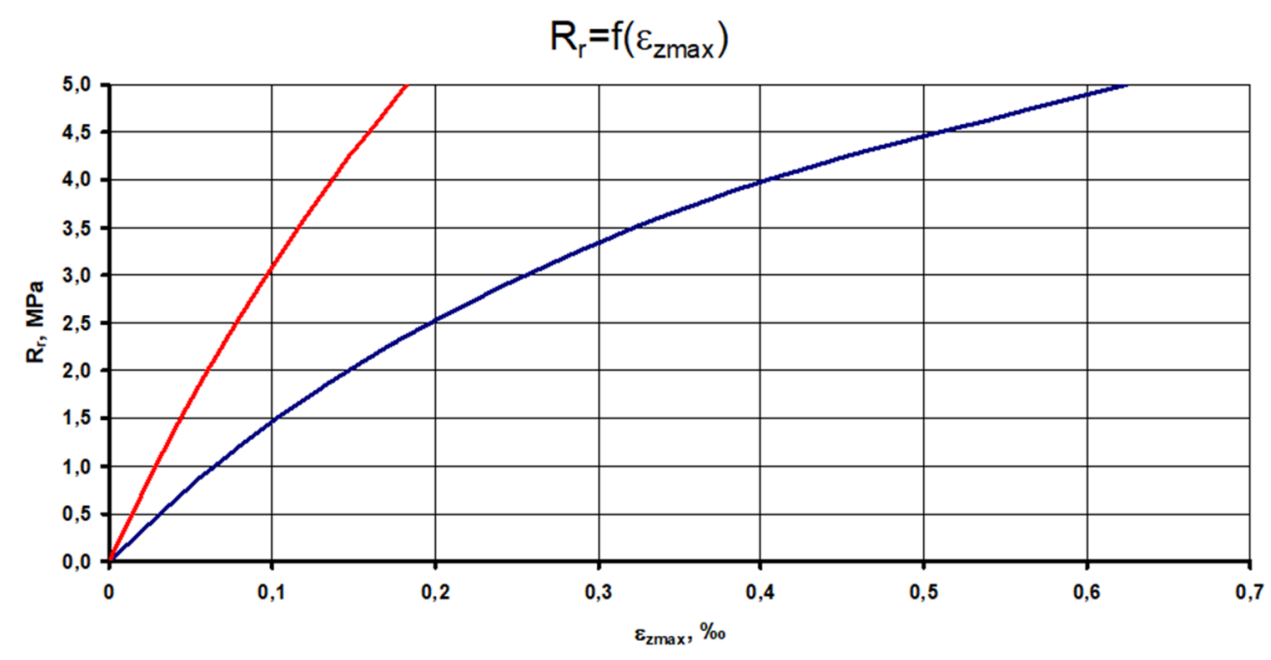


2007) confirm the results obtained by other authors (Bursztejn 1967; Hawkes and Mellor 1970; Hawkes et al. 1973; Lin et al. 2003).

The load exerted by the rock mass, resulting from the existence of fracture zones, was transferred by the support (probably wooden), which was usually left in the galleries upon their liquidation. It is beyond doubt that the largest rock mass deformations were the effect of the exploitation conducted in the years 1977-1980. If a loss of stability of the void caused by subsequent exploitations was to occur, leading to the formation of sinkholes, it should have taken place in the years 1977-1980. Moreover, if the sinkholes occurred in 2008 , it proves that the voids (workings) in the rock mass must have existed in that time. It should thus be concluded that the conducted exploitation has not caused the collapse of the workings, or at least not the entire length thereof.

\section{Other factors that may contribute to the occurrence of discontinuous deformations}

The literature study presented in the introduction indicates that increased atmospheric precipitation is a significant factor that may contribute to the formation of sinkholes, leading to the suffosion phenomenon, especially in case of existence of fractured rock mass. Due to the above, the volumes of atmospheric precipitation were analysed for the location where the sinkholes formed. Figure 11 presents a bar chart of mean monthly precipitation values obtained based on observations conducted throughout several years, as well as the precipitation registered in each month of 2007. As shown, the precipitation in September and November of 2007 considerably exceeded the typical mean values for these months. The presented information is based on the Institute of Meteorology and Water Management's data (website addresses provided at the end of the References section).

Figure 12, on the other hand, presents the chart of precipitation registered every month between September 2007 and June 2008. As shown, increased precipitation was noted in September and November of 2007, and then it was stable at the level of approx. $50 \mathrm{~mm}$.

Present-day experiences show that in the area of the Upper Silesia Basin, sinkholes are usually created in a period of approx. 2-3 months from the occurrence of increased precipitation. Such information was obtained on the basis of archival data, while conducting an investigation in the mines of the Upper Silesian Coal Basin. However, there is no published information confirming this observation, nevertheless the author conducts analysis in this regard, the results of which he plans to publish.

In conclusion, the exploitation caused occurrence of cracks in the rock mass over the working that allowed the transportation of the loose overburden by rainwater to voids and as a result sinkhole was created on the surface.
Fig. 11 Comparison of monthly mean precipitation with the precipitation in the given months of 2007

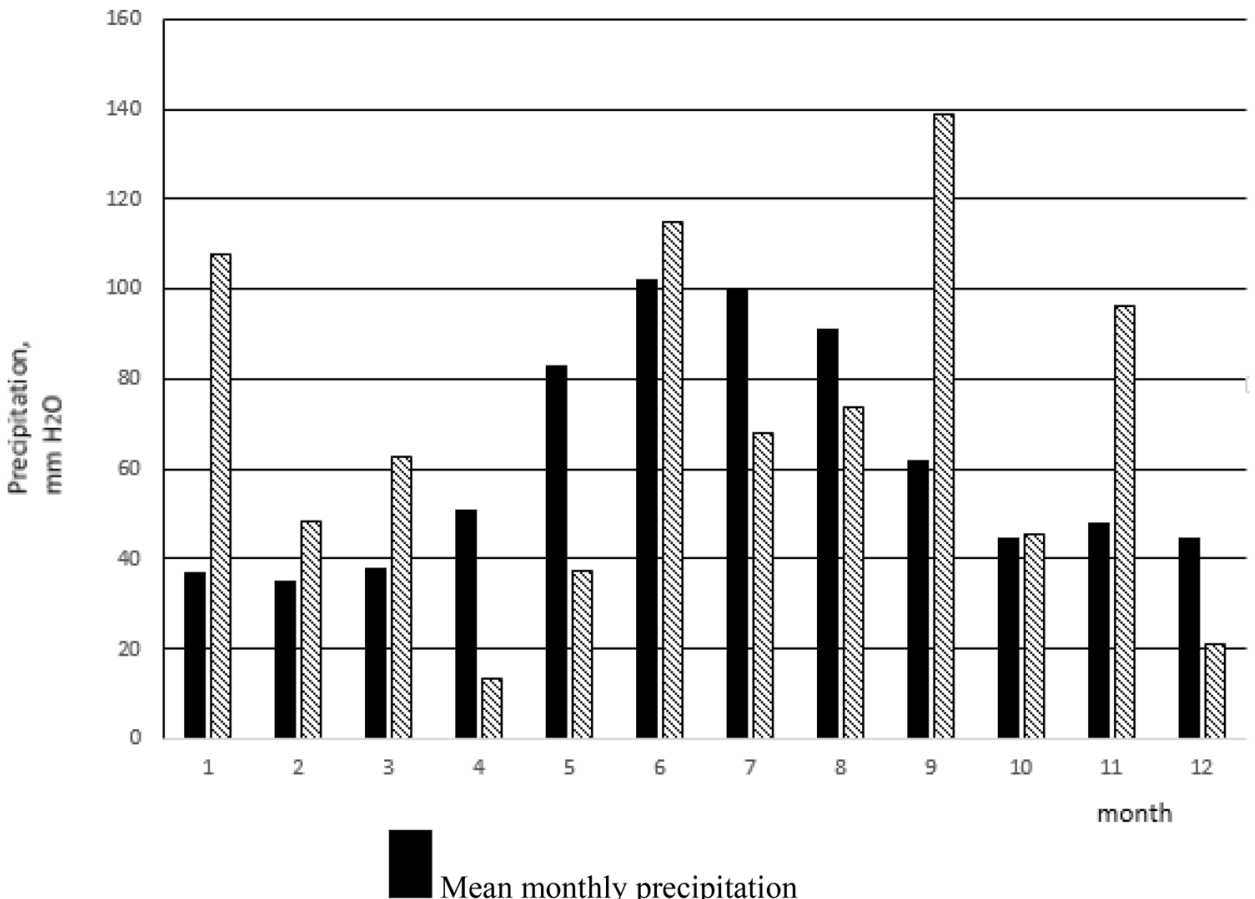

Precipitation in a given month of 2007 
Fig. 12 Monthly precipitation in the period between September 2007 and June 2008

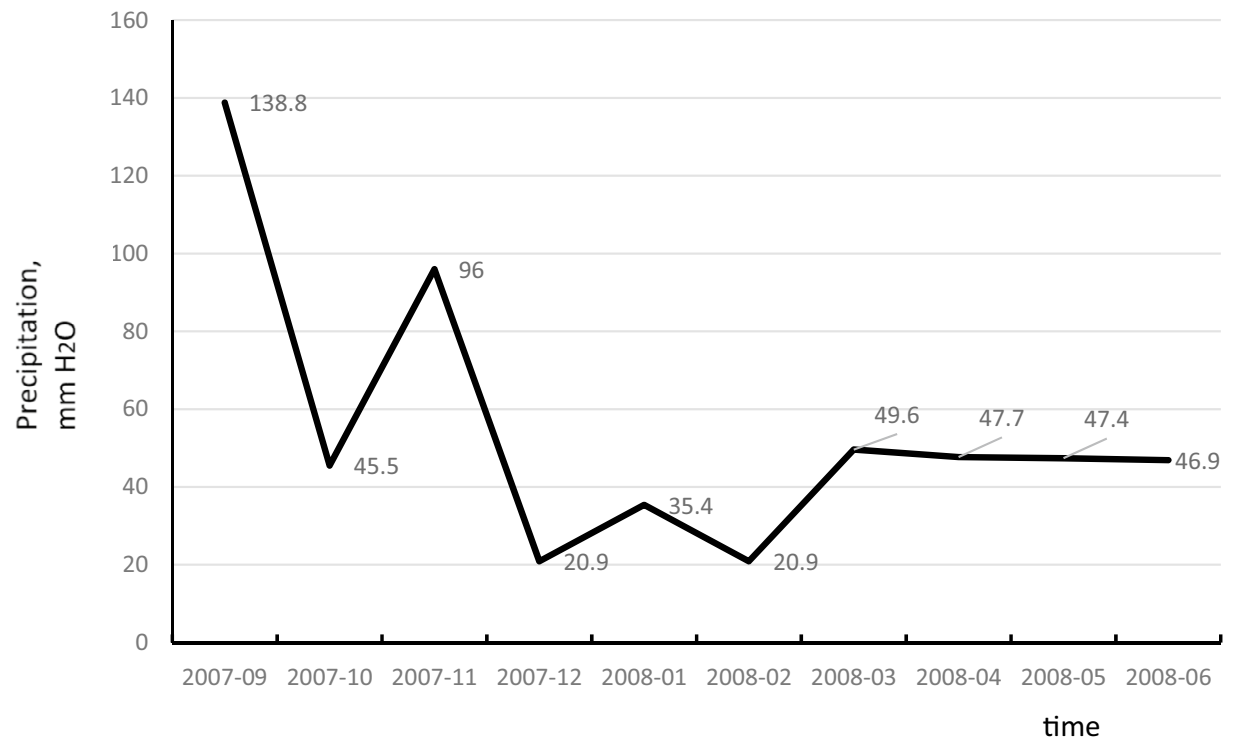

This confirms the assumption that the suffosion phenomenon is generated by precipitation, which may lead to the formation of sinkholes.

Another cause of sinkhole creation are the tremors of rock mass, caused by mining exploitation, explosives explosion, as well as vibrations caused by traffic and heavy machinery. However, in the described case those factors did not occur. Tremors of the rock mass do not occur in the conditions of the mine, no communication routes are located in the forest area and no heavy machinery was used.

\section{Determination of the probability of sinkhole formation}

The probability of sinkhole formation at the surface may be calculated by applying worked out in Poland Chudek-Olaszowski method. In its simplified version, the value of the probability $(P)$ is a function of the special indicator $Z$. The method was created on the basis of statistical analysis of the approx. 1800 sinkholes created in the area Upper Silesian Coal Basin. First, knowing the depth of the void's roof- $-\mathrm{H}$, the overburden thickness $-h$ and the void height $-g$, the value of $Z$ indicator from formula (9) should be determined. Then the probability of a sinkhole creation should be calculated using formula (10). All the necessary data can easily be determined on the basis mining maps and lithological profiles of the rock mass.

The formula for calculation of $\mathrm{Z}$ indicator may is expressed as follows (Chudek et al. 1988):

$Z=\frac{H-h}{g}$ where, $H$-depth of the void's roof, $\mathrm{m}, h$-thickness of the overburden, $\mathrm{m}, \mathrm{g}$-height of the void, $\mathrm{m}$

The value of the probability $(\mathbf{P})$ is determined by the following equation:

$P(Z)=1.34-0.036 \cdot Z+0.00019 \cdot Z^{2}$

Using the data: $\mathrm{H}=64.8 \mathrm{~m}, \mathrm{~h}=10 \mathrm{~m}, \mathrm{~g}=1.8 \mathrm{~m}$ the following result was obtained:

$Z=30.44, P(Z)=0.42$.

\section{Conclusions}

This article presents a case study of sinkhole occurrence over shallow mining gallery workings. Performed analysis of the natural and mining conditions as well as the calculations led to the conclusion that intense mining exploitation carried out in the researched area resulted in the occurrence of cracking zones and slits in the rock mass. These zones were a path for loose overburden formations transported by rainwater to the remaining gallery workings. Therefore, the phenomenon of suffosion occurred, as a result of which a number of sinkholes appeared on the surface. The presented example exhibits the hazard of sinkhole formation in every case, when there is a shallow void inside the rock mass, covered by loose overburden layers. In the Polish conditions of Upper Silesian Basin, based on practical experience, it is assumed that dangerous shallow depth of void that may trigger sinkhole arising fits into the range up to $100 \mathrm{~m}$. When planning urban development in areas where such shallow voids occur, it is necessary to use rock mass re-consolidation methods and apply adequate building protections. In general, it can be seen that in conditions of a fractured rock mass 
as a result of mining exploitation conducted under shallow voids (i.e., old mining workings), sinkholes may be expected after intense rainfalls. In connection with short-term weather forecasts, it is roughly possible to assess the sinkhole hazard.

Funding Not applicable.

Code availability The programme used for calculations is called DFK - Win (author: R.Ścigała). Tables and diagrams were made in Microsoft Excel. Figures were made in Autodesk AutoCAD.

Availability of data and material All documents are in possession of the author.

\section{Compliance with ethical standards}

Conflicts of interest I declare that there is no conflict of interests.

Open Access This article is licensed under a Creative Commons Attribution 4.0 International License, which permits use, sharing, adaptation, distribution and reproduction in any medium or format, as long as you give appropriate credit to the original author(s) and the source, provide a link to the Creative Commons licence, and indicate if changes were made. The images or other third party material in this article are included in the article's Creative Commons licence, unless indicated otherwise in a credit line to the material. If material is not included in the article's Creative Commons licence and your intended use is not permitted by statutory regulation or exceeds the permitted use, you will need to obtain permission directly from the copyright holder. To view a copy of this licence, visit http://creativecommons.org/licenses/by/4.0/.

\section{References}

Augarde CE, Lyamin AV, Sloan SW (2003) Prediction of undrained sinkhole collapse. J Geotech Geoenviron Eng 129(3):197-205. https://doi.org/10.1061/(ASCE)1090-0241(2003)129:3(197)

Baryakh AA, Fedoseev AK (2011) Sinkhole formation mechanism. J Min Sci 47(4):404-412

Bathrellos GD, Gaki-Papanastassiou K, Skilodimou HD, Papanastassiou D, Chousianitis KG (2012) Potential suitability for urban planning and industry development by using natural hazard maps and geological-geomorphological parameters. Environ Earth Sci 66(2):537-548. https://doi.org/10.1007/s12665-011-1263-x

Bell FG, Stacey TR, Genske DD (2000) Mining subsidence and its effect on the environment: some differing examples. Environ Geol 40(1-2):135-152. https://doi.org/10.1007/so0025400001

Brinkmann R, Parise M, Dye MD (2008) Sinkhole distribution in a rapidly developing urban environment: Hillsborough County, Tampa Bay, Florida. Eng Geol 99(3-4):169-184

Bursztejn LS (1967) Diagramy rastiażenija i sżatija piesczanika. Fiziko-tiechniczieskije problemy razrabotki poleznych iskopajemych 1: 24-29

Chudek M, Janusz W, Zych J (1988) Study on diagnosis and prognosis of the formation of discontinuous deformation due to underground mining. Zeszyty Naukowe Politechniki Śląskiej, seria Górnictwo, Vol. 141, Gliwice (in Polish)

Doctor K et al. (2008) Predicting sinkhole susceptibility in Frederick Valley, Maryland using geographically weighted regression. 11th Multidisciplinary Conference on Sinkholes and the Engineering and Environmental Impacts of Karst 2008. September 22-26, 2008 Tallahassee, Florida, United States

Gutiérrez F, Cooper AH, Johnson KS (2008) Identification, prediction, and mitigation of sinkhole hazards in evaporite karst areas. Environ Geol 53(5):1007-1022. https://doi.org/10.1007/s0025 4-007-0728-4

Hawkes I, Mellor M (1970) Uniaxial testing in rock mechanics laboratory. Eng Geol 4:266-267

Hawkes I, Mellor M, Gariepy S (1973) Deformation of rocks under uniaxial tension. Int J Rock Mech Min Sci Geomech Abstr 10:493-507

https://dane.imgw.pl/data/dane_pomiarowo_obserwacyjne/

https://pl.climate-data.org/europa/polska/silesian-voivodeship

Hunter J (2015) Old mines and new sinkholes along the Hucklow Edge vein, Derbyshire. Am Geol 18(4):213-226

Jiang X, Lei M, Gao Y (2017) Formation mechanism of large sinkhole collapses in Laibin, Guangxi, China. Environ Earth Sci 76:823. https://doi.org/10.1007/s12665-017-7128-1

Kidybiński A (1982) Basics of mining geotechnics. 'Śląsk' Publishing House, Katowice (in Polish)

Knothe S (1984) Forecasting the impact of mining exploitations. 'Śląsk' Publishing House. Katowice (in Polish)

Kratzsch H (1983) Mining subsidence engineering. Springer-Verlag, Berlin, Heidelberg, New York

Li G, Zhou W (1999) Sinkholes in karst mining areas in China and some methods of prevention. Eng Geol 52(1-2):45-50. https:// doi.org/10.1016/S0013-7952(98)00053-2

Lin W, Kamei A, Takahashi M, Kwasniewski M, Takagi T, Endo H (2003) Deformability of various granitic rocks from Japan in uniaxial tension. ISRM 2003 - Technology Roadmap for Rock Mechanics, South African Institute of Mining and Metallurgy: 787-790

Malinowska A, Matonóg A (2017) Sinkhole hazard maping with the use of spatial analysis and analytical hierarchy process in the light of mining-geological factors. Acta Geodyn Geomater 14(2):159-172

Mellett JS, MacCarillo BJ (1996) A model for sinkhole formation on interstate and limited access highways, with suggestions on remediation. Int J Rock Mech Min Sci Geomech Abstr 33(2):A85

Papadopoulou-Vrynioti K, Bathrellos GD, Skilodimou HD, Kaviris G, Makropoulos K (2013) Karst collapse susceptibility mapping considering peak ground acceleration in a rapidly growing urban area. Eng Geol 158:77-88

Pilecki Z (2008) The role of geophysical methods in the estimation of sinkhole threat in the post-mining areas of shallow exploitation in the Upper Silesian Coal Basin, Poland. Miner Resour Manag 24(3):27-40

Sałustowicz A (1956) An outline of rock mass mechanics. 'Śląsk' Publishing House. Katowice (in Polish)

Scarborough JA (1996) Risk and reward: pipes and sinkholes in east Tennessee. Int J Rock Mech Min Sci Geomech Abstr 33(2):A74

Ścigała R (2013) The identification of parameters of theories used for prognoses of post mining deformations by means of present software. Arch Min Sci 58(4):1347-1357. https://doi.org/10.2478/ amsc-2013-0093

Singh KB, Dhar BB (1997) Sinkhole subsidence due to mining. Geotech Geol Eng 15(4):327-341. https://doi.org/10.1007/BF008 80712

Strzałkowski P (2019) Sinkhole formation hazard assessment. Environ Earth Sci 78:9. https://doi.org/10.1007/s12665-018-8002-5

Strzałkowski P, Ścigała R (2010) Determination of the duration of surface subsidence caused by underground extraction. Schriftenfreihe des Institutes fur Markscheidewewsen und Geodäsie an der Technischen Universitat Bergakademie Freiberg: 77-81 
Strzałkowski P, Tomiczek K (2015) Proposal of a methodology assessing the risk of sink holes formation in mining areas. Int J Min Sci Technol 25(1):85-89

Tomiczek K (2007) On behaviour of rocks in tensile stress conditions. Budownictwo Górnicze i Tunelowe. Wydawnictwo Górnicze, Katowice 2007(1): 38-44 (in Polish)

Whittaker BW, Redish DJ (1989) Subsidence: occurrence, prediction and control. Elsevier, Amsterdam-Oxford-New York-Tokyo

Xiao H, Kim YJ, Nam BH, Wang D (2016) Investigation of the impacts of local-scale hydrogeologic conditions on sinkhole occurrence in East-Central Florida, USA. Environ Earth Sci 75:1274
Publisher's Note Springer Nature remains neutral with regard to jurisdictional claims in published maps and institutional affiliations. 